\title{
A CASE OF MANGANESE PRECIPITATE IN THE TAVIHARJU ESKER, KUUSAMO, NORTH EAST FINLAND
}

\author{
Yrjö Vasari, Tapio Koljonen and Keijo LaAkso
}

\begin{abstract}
Yrjö Vasari, Tapio Koljonen and Keijo LaAkso 1972: A case of manganese precipitate in the Taviharju esker, Kuusamo, North East Finland. Bull. Geol. Soc. Finland 44, 133-140.
\end{abstract}

A manganese-iron precipitate of an exceptional size has been found in the Taviharju esker in Kuusamo, North-East Finland. The different forms in which manganese is known to be deposited in humid areas such as Finland are listed. The Taviharju case represents an example of cementation in gravel and coarse sand. The mechanism operates in the following way: Manganese and iron have been dissolved in reduced form, probably as complex organic compounds, in percolating ground water. When the water enters coarse esker material where oxidizing conditions prevail, the manganese, iron and dissolved organic compounds are oxidized and precipitated as electrically charged gels. These coat the mineral grains and cement them together to form horizontal layers rich in manganese. The soil may be termed gleyed.

Yrjö Vasari, Department of Botany, University of Oulu, Finland.

Tapio Koljonen, Department of Geology and Mineralogy, University of Helsinki, Helsinki, Finland.

Keijo Laakso, Department of Geology and Palaeontology, University of Helsinki, Helsinki, Finland.

\section{Introduction}

Only one major soil region is represented in Finland, the Atlantic podsol (Papadakis 1969, p. 122). The soils of the dominant vegetation type, the coniferous forests, are almost exclusively podsolic soils in which iron is precipitated on the soil particles as a $B_{I R}$ layer. Ironhydroxide is commonly deposited, not only in soils but also as bog and lacustrine ore and as a sea-bottom deposit along the Finnish coast (Aarnio 1917,
Frosterus 1914 and Winterhalter 1966). The lacustrine ores were in the past widely used in local iron industries and because of their high content of manganese they served again as ores during the Second World War (cf. e.g. Winterhalter 1966, p. 72).

Of the exogenic factors the climatic conditions are of paramount importance to the geochemical behaviour of iron and manganese. The migrations of these elements through a profile show similar features although they do not behave in 
an entirely identical way but tend to enrich different parts of the same formation.

The precipitation process for manganese, probably mainly as $\mathrm{MnO}_{2}$ (Rankama and Sahama 1964, pp. 647-648) is divisible into distinctly different types although in all of them the basic reason is the change of $\mathrm{Mn}^{+2} \rightarrow \mathrm{Mn}\left({ }^{+3}\right),{ }^{+4}$ by oxidization.

A. Enrichment residue ("Gossans»): Manganese tends to enrich the weathered parts of those rocks with a high initial manganese content (Saxén 1925, pp. 14, 24 and Hietanen 1936, p. 391).

\section{B. Concentration and manganese concretions in a} basic milieu: When basic rocks, especially limestones, are weathered, the surroundings are neutral or only weakly acidic. Manganese becomes oxidized because of the high $\mathrm{pH}$ and is precipitated from percolating waters or in situ on weathering rock. Limestones contain commonly some $\mathrm{Mn}^{+2}$ which has replaced calcium. During the weathering process both $\mathrm{Ca}$ and $\mathrm{Mg}$ are dissolved, but the manganese is then oxidized and enriches the weathering products (Repo and Winterhalter 1968, p. 120). - This enrichment phenomenon is probably analogous to the formation of brunisolic soils (Papadakis 1969, p. 38) in which manganese is in an insoluble form and migrates only little ( $c f$. also Stålfelt 1965, pp. $314-315)$.

C. Coating on rocks and sand in brooks and rivers: Quite commonly manganese is oxidized by atmospheric oxygen in brooks and rivers and forms a thin dark coloured layer of $\mathrm{Mn}^{+4}$-oxides on rock and mineral particles (Goldschmidt 1958, p. 634). This coating is usually very thin, but may sometimes reach a thickness of some centimetres.

\section{Cementation in gravel and coarse sand (in glacio-} fluvial deposits): Dark coloured small concretions and concretionary horizons are found in sands. The phenomenon is due to the oxidization of the
$\mathrm{Mn}^{+2}$ present in percolating water by atmospheric oxygen. U. ually these formations are small, but occasionally may even reach a thickness of some metres. The Taviharju precipitate represents this type.

\section{The geochemistry of manganese in exogenic processes in Finland}

Manganese is present in the rocks mostly as a mangano ion which substitutes iron in melanocratic minerals. These (amphiboles, pyroxenes and micas) are most easily weathered and thus the mangano ion becomes dissolved in percolating water. In a cool humid area such as Finland which is mainly covered by coniferous forests and mires the ground water generally tends to be acidic with a high content of low polymerized organic acids. Because of this acidity, the cations $\mathrm{Fe}^{+2}$ and $\mathrm{Mn}^{+2}$ are easily dissolved in the circulating water. The decomposing organic compounds maintain reducing conditions in the soil, thus preventing the oxidization of $\mathrm{Fe}^{+2}$ and $\mathrm{Mn}^{+2}$. The behaviour of manganese in different soils has been studied in Western Siberia by Mal'gin (1969, p. 61) who observed the high mobility of manganese in forest soils.

One more reason why iron and manganese remain in solution is the fact that they form chemically very stable complex soluble compounds with the organic acids in ground water which are formed during the decomposition of plant remains. These compounds are destroyed when the organic component is decomposed or when the anion is oxidized. This process is promoted by biotic factors, especially by bacteria and fungi, mainly in aerobic conditions. The polymerized organic compounds, $\mathrm{Fe}^{+3}$ and $\mathrm{Mn}\left({ }^{+3}\right),{ }^{+4}$ -oxides and -hydroxides are precipitated, and forming electrically charged particles they tend to adhere to such angular soil components as sand grains.

Manganese and iron with a high valency form oxides and hydroxides which are not easily 

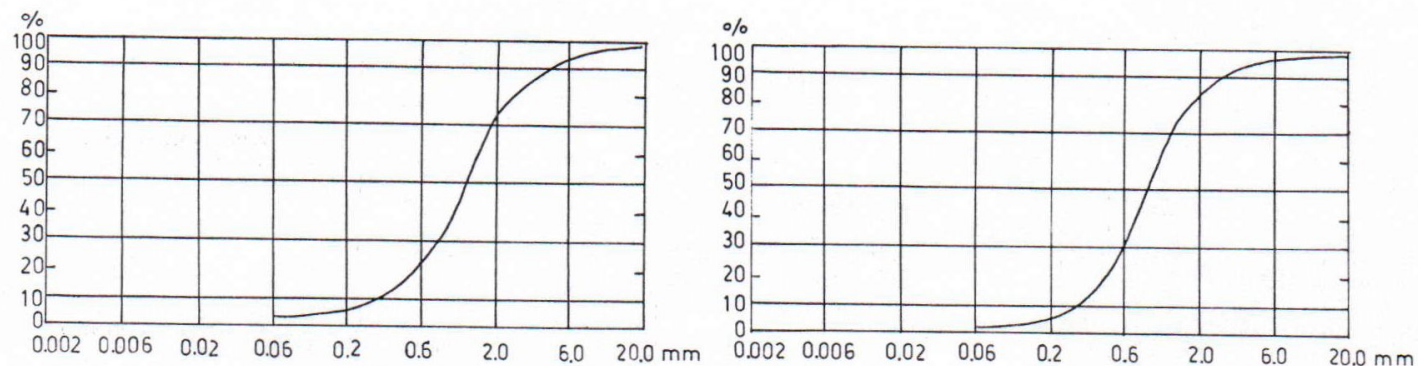

FIG. 1. Grain-size analyses of the main material in the esker (on the left) and of the material in the upper terrace (on the right).

soluble. Manganese does not oxidize to the soluble permanganate ion in natural conditions in Finland.

\section{Materials and methods}

\section{A. Description of the site}

Taviharju, where the formation in question was found, is a rather narrow, low, supraaquatic esker running in a south-east - northwest direction along the southern slopes of Maanselkä, about $15 \mathrm{~km}$ to the southwest of Kuusamo village (6552' N Lat, $28^{\circ} 57^{\prime} \mathrm{E}$ Long). The esker forms a step or low barrier between two small, boggy terraces.

The main material of the esker is coarse sand (cf. Fig. 1). This also forms the basis of the upper terrace. There it, however, is overlain by a layer about $40 \mathrm{~cm}$ thick, of cultivated soil with an organic content of $17.8 \%$. This terrace is at present being cultivated and a brook running through it has been recently cleared to serve as the main ditch for the field.

The esker has been used as a sand quarry and has been cut throughout its length. The cuttings have revealed a frequent, almost continuous occurrence, of dark cemented material, often of considerable thickness (Fig. 2).

At the point where this dark horizontal layer is well developed and over one metre thick, a monolith about $15 \times 15 \times 120 \mathrm{~cm}$ was removed, preserving the structure for laboratory investiga- tions. The hard column was divided into 32 samples (numbered from top to bottom) (Fig. 3) (the small silty veins in it were investigated separately). The samples were ground with a vibrating mill »Schwingmühle» manufactured by Messers. Siebtechnik G. M. B. H., Mülheim, West Germany, homogenized and analysed without any sieving. The powder, about 200 mesh, was dried at $110^{\circ} \mathrm{C}$ to constant weight. The particle size was determined by sieving alone.

\section{B. Chemical analysis of the inorganic fraction}

$1-2 \mathrm{~g}$ of the sample were transferred to a $400 \mathrm{ml}$ teflon dish and $100 \mathrm{ml} \mathrm{H} \mathrm{H}_{2} \mathrm{O}, 10 \mathrm{ml} 30 \% \mathrm{H}_{2} \mathrm{O}_{2}$ (Merck z. A. 7209) and (cautiously) $20 \mathrm{ml} 37 \% \mathrm{HCl}$ (Merck z. A. 317) were added. The dish was transferred to a water

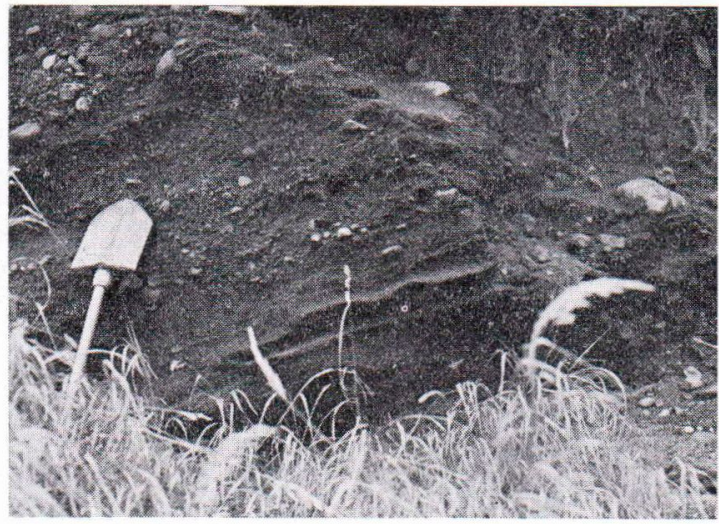

FIG. 2. Detailed picture of the horizontal layering of the manganese precipitate in Taviharju esker. Photo J. Donner. 


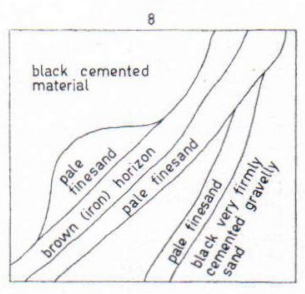

14

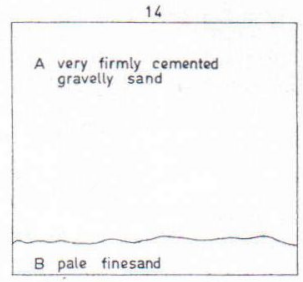

16.
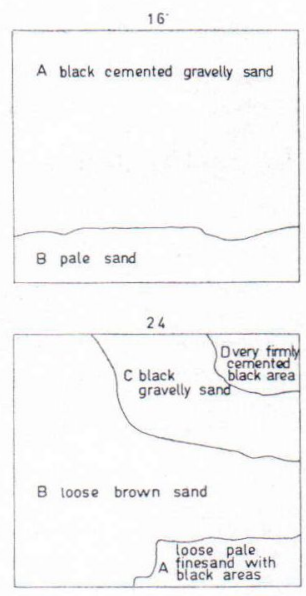

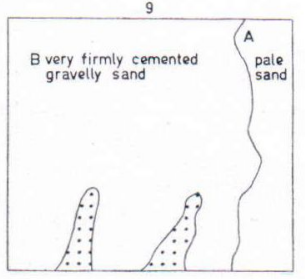

15

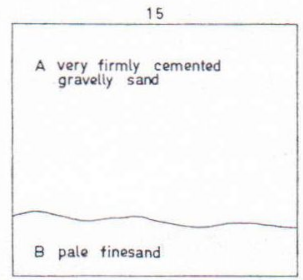

23

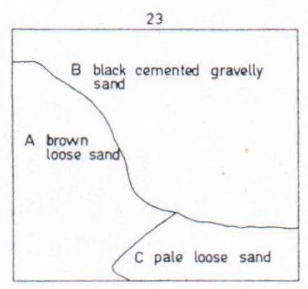

$\cdots$ pale finesand

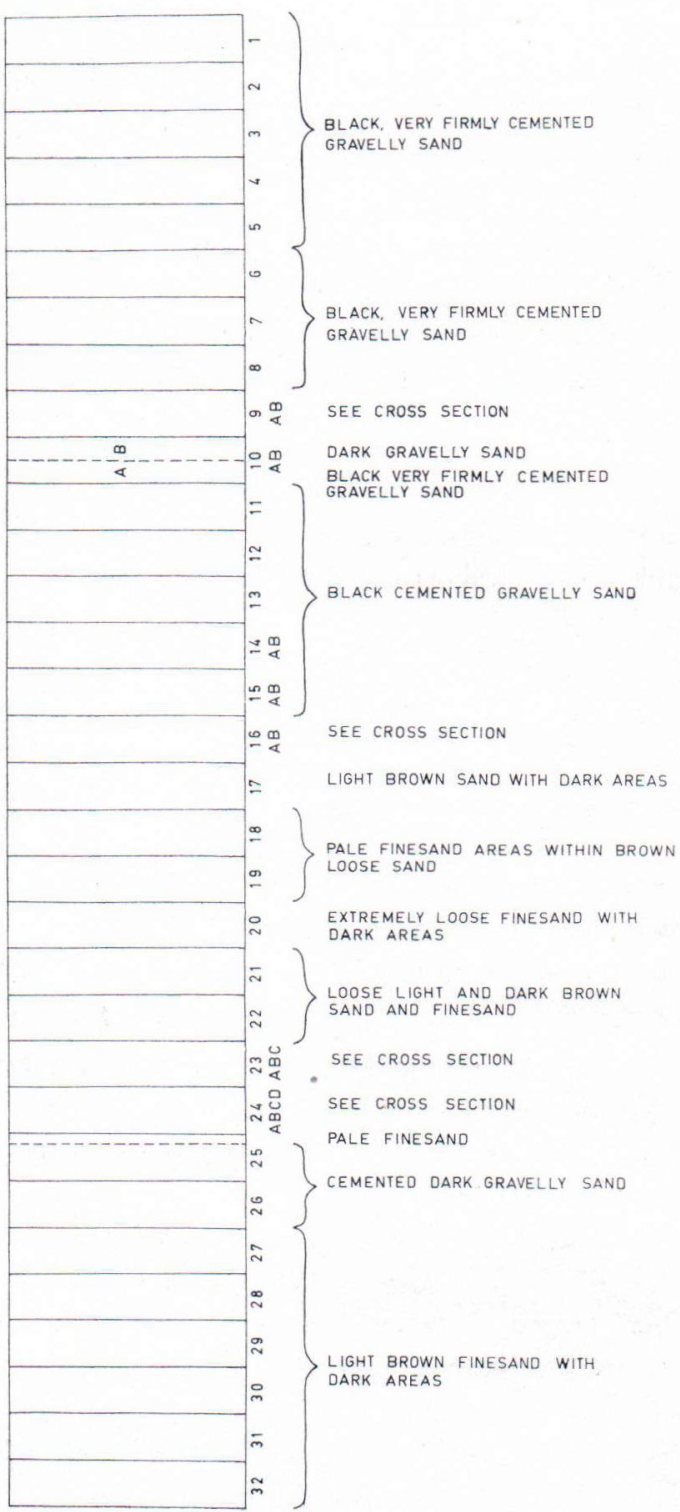

FIG. 3. The structure of the monolith and its division into samples (No. 1 is the topmost sample). The squares on the left are horizontal sections.

bath and evaporated to dryness. During the addition of reagents it was covered with a watch glass, which was removed and washed when the bubbling had ceased. The reagents were added once more and when the dark iron and manganese compounds had dissolved, the solution was filtered through a fast paper. The undissolved sand was washed with dilute $\mathrm{HCl}$.
The paper with the precipitate was ignited $\left(1100^{\circ} \mathrm{C}\right)$ and weighed. By this solution method, which is not in common use in analytical chemistry, manganese and iron compounds are reduced and dissolved as chlorides and organic compounds are destroyed. The method is useful, especially when the sample contains sand, because the manganese oxides are not easily dissolved by common 
analytical methods and the mineral grains are only slightly attacked by dilute acid as silica does not dissolve much in an acid solution.

The solution process for manganese may be described by the formula: $\mathrm{MnO}_{2}+\mathrm{H}_{2} \mathrm{O}_{2}+2 \mathrm{HCl} \rightarrow \mathrm{MnCl}_{2}+$ $2 \mathrm{H}_{2} \mathrm{O}+\mathrm{O}_{2}$.

The filtrate was transferred to a $700 \mathrm{ml}$ beaker and the sesquioxides were precipitated with ammonia. The precipitate was then transferred to a crucible and ignited. The ignition residue was dissolved by potassium pyrosulphate fusion. The separation was made according to the classical wet silicate analysis method (e.g. Maxwell 1968, pp. 100 101, 345-348).

The filtrate from the ammonia solution and the dissolved pyrosulphate fusion were transferred to volumetric flasks and analysed separately. The separation of the solutions is not necessary for the atomic absorption spectroscopy, but was thought to be useful for lessening the interference between elements. It was especially important to separate phosphorus, the content of which may be high in this type of formation, from calcium, because the interference of phosphate in the calcium analysis by AA may cause analytical errors (Slavin 1968, p. 89). The separation with ammonia is not quantitative for many elcments. Therefore the analysis of manganese should be made from both solutions and the contents of trace elements checked.

\section{Chemical analysis of the organic fraction}

The organic fraction was determined by loss on ignition (at $550^{\circ} \mathrm{C}$ ). The humic and fulvic acids were separated from the sample by extracting with $10 \%$ ammonia (Meurice and Martens 1934). Ammonia was preferred, as because of its volatility it can be easily removed. The solution containing the organic acids was centrifuged and the humus content was determined by carbon analysis. The carbon content was analysed as $\mathrm{CO}_{2}$ by igniting the sample at $600^{\circ} \mathrm{C}$ in an oxygen stream.

The amount of humus was determined using the coefficient 1.9 (Heinonen 1960, p. 126) when the carbon content is known.

The infra-red spectroscopical analysis of humus was made with a Leitz double-beam infra-redspectrometer M III.

\section{Results of the analyses}

The cementing material is mostly manganese, probably $\mathrm{MnO}_{2}$ containing some iron and humic acids (Table 1).
TABle 1.

The contents of manganese, iron, humic and organic matter in different parts of the concretion. (All values as percentages of dry weight).

\begin{tabular}{|c|c|c|c|c|c|}
\hline & $\begin{array}{c}\text { Sample } \\
\text { n:o }\end{array}$ & $\begin{array}{l}\text { Organic } \\
\text { matter }\end{array}$ & $\begin{array}{l}\text { Humic } \\
\text { acids }\end{array}$ & $\begin{array}{l}\text { Total } \\
\text { iron }\end{array}$ & Manganese \\
\hline 1 & $\ldots \ldots$ & 1.00 & 0.096 & 0.71 & 1.67 \\
\hline 2 & $\ldots \ldots$ & 0.82 & 0.156 & 0.50 & 1.94 \\
\hline 3 & $\ldots \ldots$ & 0.87 & 0.160 & 0.58 & 1.90 \\
\hline 4 & $\ldots \ldots$ & 0.79 & 0.024 & 0.46 & 1.67 \\
\hline 5 & $\ldots \ldots$ & 0.92 & 0.128 & 0.39 & 1.74 \\
\hline 6 & $\ldots \ldots$ & 0.62 & 0.120 & 0.40 & 1.59 \\
\hline 7 & $\ldots \ldots$ & 0.63 & 0.114 & 0.39 & 1.55 \\
\hline 8 & $\ldots \ldots$ & 0.55 & 0.112 & 0.38 & 1.72 \\
\hline 9. & A $\ldots$ & 0.47 & 0.068 & 0.31 & 0.69 \\
\hline 9 & B $\ldots$ & 0.66 & 0.114 & 0.27 & 1.31 \\
\hline 10 & $A \ldots$ & 0.62 & 0.072 & 0.34 & 0.91 \\
\hline 10 & $B \ldots$ & 0.62 & 0.124 & 0.30 & 1.62 \\
\hline 11 & $\ldots \ldots$ & 0.62 & 0.100 & 0.32 & 1.25 \\
\hline 12 & $\ldots \ldots$ & 0.60 & 0.126 & 0.38 & 1.66 \\
\hline 13 & $\ldots \ldots$ & 0.79 & 0.128 & 0.40 & 1.61 \\
\hline 14 & A $\ldots$. & 0.68 & 0.115 & 0.47 & 1.48 \\
\hline 14 & B $\ldots$ & 0.63 & 0.078 & 0.28 & 0.86 \\
\hline 15 & $A \ldots$ & 0.65 & 0.156 & 0.58 & 0.91 \\
\hline 15 & $B \ldots$ & 0.45 & 0.135 & 0.47 & 0.83 \\
\hline 16 & $\ldots \ldots$ & 0.43 & 0.050 & 0.51 & 0.65 \\
\hline 17 & $\ldots \ldots$ & 0.32 & 0.040 & 0.42 & 0.62 \\
\hline 18 & $\ldots \ldots$ & 0.34 & 0.039 & 0.42 & 0.78 \\
\hline 19 & $\ldots \ldots$ & 0.42 & 0.037 & 0.38 & 0.94 \\
\hline 20 & $\ldots \ldots$ & 0.43 & 0.038 & 0.41 & 1.13 \\
\hline 21 & $\ldots \ldots$ & 0.45 & 0.066 & 0.43 & 1.16 \\
\hline 22 & $\ldots \ldots$ & 0.50 & 0.062 & 0.39 & 1.22 \\
\hline 23 & $A \ldots$ & - & - & 0.36 & 0.69 \\
\hline 23 & $B \ldots$ & 0.63 & 0.123 & 0.45 & 1.43 \\
\hline 24 & $A \ldots$ & 0.50 & 0.088 & - & - \\
\hline 24 & B $\ldots$ & 0.38 & 0.060 & 0.43 & 0.45 \\
\hline 24 & $C \ldots$ & 0.60 & 0.132 & 0.59 & 1.64 \\
\hline 25 & $\ldots \ldots$ & 0.43 & 0.084 & 0.39 & 1.19 \\
\hline 26 & $\ldots \ldots$ & 0.68 & 0.116 & 0.39 & 1.42 \\
\hline 27 & $\ldots \ldots$ & 0.50 & 0.160 & 0.38 & 1.13 \\
\hline 28 & $\ldots \ldots$ & 0.54 & 0.084 & 0.42 & 0.78 \\
\hline 29 & $\ldots \ldots$ & 0.43 & 0.040 & 0.36 & 0.81 \\
\hline 30 & $\ldots \ldots$ & 0.41 & 0.095 & 0.31 & 0.53 \\
\hline 31 & $\ldots \ldots$ & 0.41 & 0.114 & 0.32 & 0.26 \\
\hline 32 & $\ldots \ldots$ & 0.42 & 0.115 & 0.48 & 0.28 \\
\hline
\end{tabular}

The correlatior between humic acids and manganese (Fig. 4) is evident. Accordingly, it can be assumed that manganese has been brought to the formation as an organic-complex ion. When precipitated compounds, humic acids, manganesedioxides and -hydroxides and ironhydroxides, are electrically charged, especially when they are oppositely charged they coagulate and form mixed aggregates.

Analyses were also made of the water in the brooks draining the upper terrace and running 


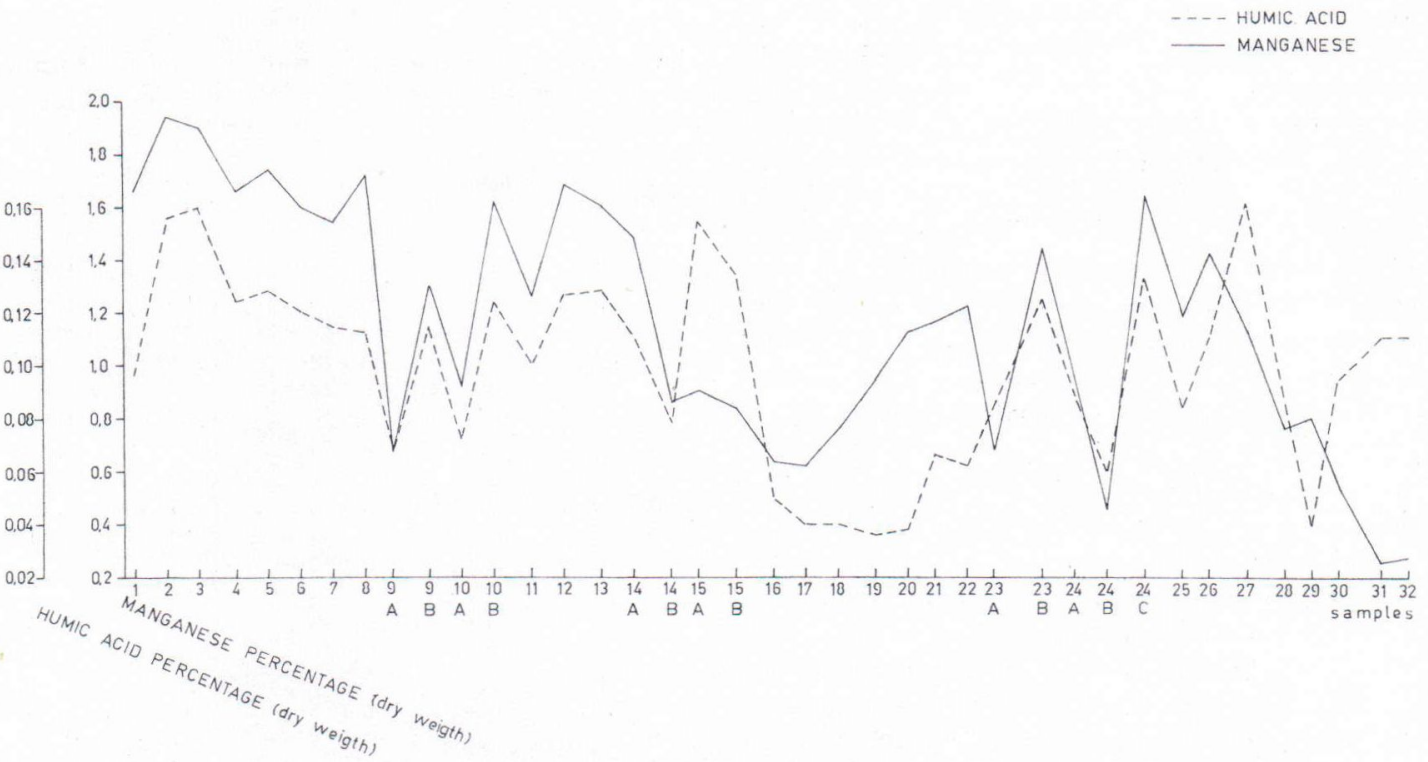

FIG. 4. The correlation between humic acids and manganese.

through the esker. Tne average of three samples was $0.5 \mathrm{mg}$ iron, $0.05 \mathrm{mg}$ manganese and $0.03 \mathrm{mg}$ humic acids per liter.

In the infra-red absorption spectra (Fig. 5) of the separated humic acid fraction absorption bands in the $3505 \mathrm{~cm}^{-1}$ range, characteristic of the carboxyl group (Bolker and Somerville 1963, pp. 3-4) and the $3100-2950 \mathrm{~cm}^{-1}$ range, characteristic of the $\mathrm{C}-\mathrm{H}$ type of bond (Nakanishi 1962 , p. 26) can be observed. The absorp- tion in the $1590-1640 \mathrm{~cm}^{-1}$ range is typical of aromatic compounds and in the $1400 \mathrm{~cm}^{-1}$ range of the methoxy group. The broad absorption, the maximum of which is in the $1025 \mathrm{~cm}^{-1}$ range, is probably caused by alcohol groups (Bolker and Somerville 1963, p. 3).

In the infra-red spectra three major groups, viz. aromatic, carboxyl and alcohol, can thus be observed ( $c f$. the spectra presented by Kononova 1966, p. 67).

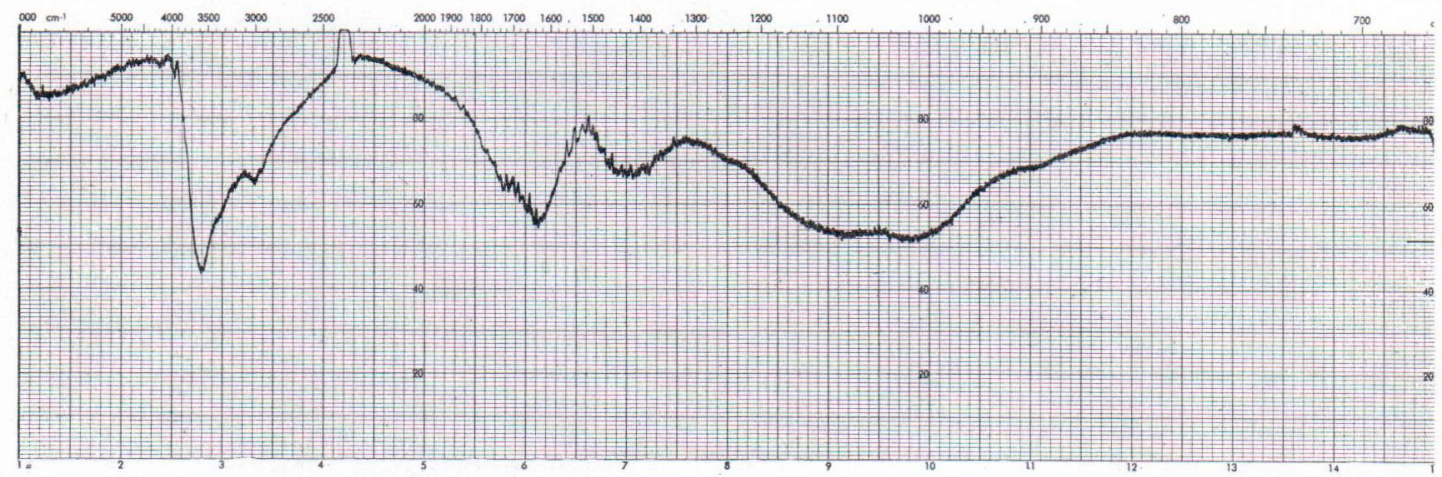

Fig. 5. Infra-red spectra of the humic acid. 


\section{The genesis of the formation}

Highly siliceous rocks predominate in the area (Matisto 1958). The surface horizons of the upper terrace immediately above the esker are markedly acid with a $\mathrm{pH}$ of 4.3 for the cultivated soil and a $\mathrm{pH}$ of 4.8 about $40 \mathrm{~cm}$ deeper down, in the upper part of the coarse sand. A marked contrast prevails, however, between the $\mathrm{pH}$ values of the terrace soil and the esker material itself. A series of measurements from the place where the sample monolith was taken gave the following values: $5.8(10 \mathrm{~cm}), 6.0(25 \mathrm{~cm})$ and $6.7(200 \mathrm{~cm}=$ sample 32, cf. Fig. 3). (The $\mathrm{pH}$ measurements were made in the field using a Radiometer PHM 24 e).

The mechanism leading to the precipitation of manganese and iron in the esker is thought to have operated along the following lines: The ground water contains much organic, fulvic and humic acid and accordingly has a low $\mathrm{pH}$ value. Thus it also has a high elluviating capacity. The dissolved cations are in reduced form and can migrate with percolating waters as ions, fulvates, humates and organic compounds. When the milieu changes from anaerobic conditions to aerobic and more oxidizing ones, the organic acids become neutralized and $\mathrm{Mn}^{(+3)},{ }^{+4}, \mathrm{Fe}^{+3}$, and organic compounds are precipitated. Because the sols formed are electrically charged they form water containing gels. The gels adhere to angular mineral grains (Fig. 6) and partly fill the cavities in gravel.

The difference in porosity causes the oxygen content to be higher in the coarser materials of the esker than in the finer. The upper level of the ground water fluctuates seasonally. When the level sinks, the gels become dehydrated and bond by polaric absorption. The chemical bonds betwreen particles are strengthened and mixed hydroxide - oxide concretions are formed between manganese, iron and organic compounds. The process is irreversible and when the ground water rises again the concretions around the soil particles are not easily dissolved. In this

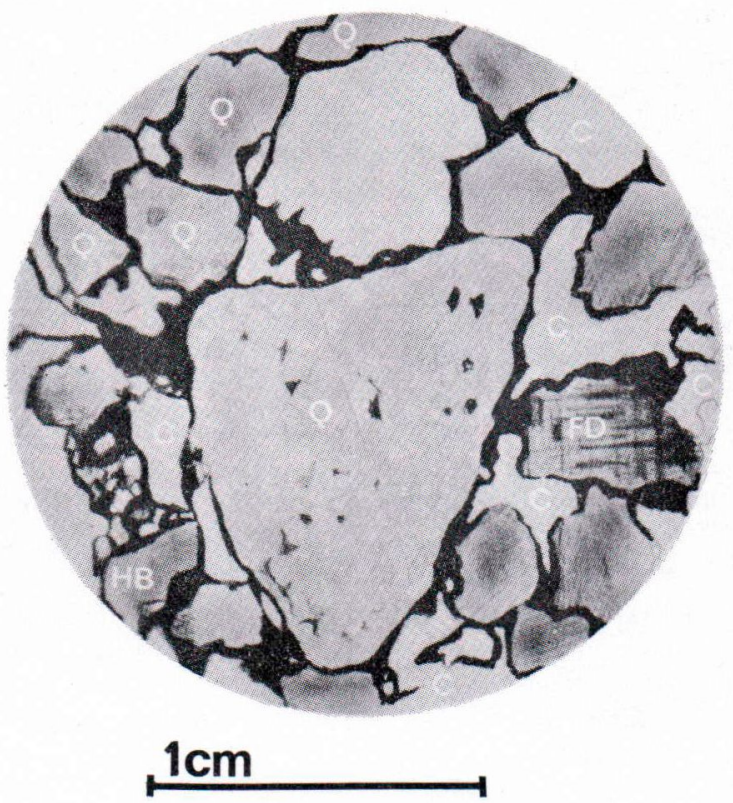

FIG. 6. Gravel particles coated and cemented with dark manganese precipitate. Q(quartz), HB(hornblende), $\mathrm{FD}$ (feldspar) and $\mathrm{C}$ (cavity).

way the higher amount of precipitate in the upper part of the investigated formation can also be explained since the oxidization process is stronger there. During a period of high ground water level manganese tends to migrate upwards because it is partly dissolved in the lower horizons. The grain size of the deposit is also significant to the growth of concretions, as a deposit with a coarser structure is better aerated.

The narrow finesand veins contain appreciably less concretionary components and are light in colour. They do not dry as easily as the coarse parts and are more reducing than the surroundings. The dissolved components migrate with moisture to the coarser parts and the content of manganese and iron is lower in the finer parts.

The soil as a whole may be termed gleyed (Scheffer and Schachtschabel 1966, pp. $361-$ 362; Vilenskii 1957, pp. 308-309; cf. also 
Frosterus 1914: Grundwasserpodsol). A typical feature of these gleyed soils is the nearly horizontal layering. Iron is commonly elluviated in the waterlogged parts of the soil.
Acknowledgements - The financial support given by the National Research Council is gratefully acknowledged. The authors further want to thank Prof. J. Donner for much fruitful discussion and help, Mrs. Sheila P. Hicks, $\mathrm{Ph}$. D., for correcting the English manuscript and Miss Raija Tikkanen for preparing the diagrams.

\section{REFERENCES}

Aarnio, B. (1917) Järvimalmit eräissä Pusulan, Pyhäjärven, Lopen, Someroniemen ja Tammelan järvissä. Geotekn. Tied. No. 20.

Bolker, H. I. \& Somerville, N. G. (1963) Infrated Spectroscopy of Lignins. Pulp. Paper Mag. Canada 64, No. 4: T - 187 - T 194 (April, 1963).

Frosterus, B. (1914) Zur Frage nach der Einteilung der Böden in Nordwest-Europas Moränengebieten. Geotekn. Meddel. No. 14.

Goldschmidt, V. M. (1958) Geochemistry. Oxford University Press, London.

Heinonen, R. (1960) Density, Amount and Carbon Content of Organic Matter in Soils - Some Methodical Reflections. Maataloustiet. Aikakauskirja 32, 2.

Hietanen, A. (1936) Über den Rhodonit und andere Manganminerale von Simsiö, Pohjanmaa. C. R. géol. Finlande IX, Bull. Comm. géol. Finlande No. 115.

Kononova, M. M. (1966) Soil Organic Matter. Pergamon Press, London.

MAL'GIN, M. A. (1969) Distribution of mobile manganese in soils of the Gormo-Altai. In: Kovalev, R. V. (Ed.), Genesis of the Soils of western Siberia. Jerusalem.

Matisto, Arvo (1958) Suomen geologinen yleiskartta. Lehti D 5 Suomussalmi. Kivilajikartan selitys. Geologinen tutkimuslaitos, Otaniemi.

Maxwell, J. A. (1968) Rock and mineral analysis. Interscience Publishers, New York-London-Sidney -Toronto.
Meurice, R. \& Martens, P. (1934) The determination of ammonia-soluble humus. Bull. Inst. agron. Gemgloux 3.

NAKANISHI, K. (1962) Infrared Absorption Spectroscopy. Tokio.

Papadakis, J. (1969) Soils of the World. Elsevier Publishing Company, Amsterdam.

Rankama, K. \& Sahama, Th. G. (1950) Geochemistry. University of Chicago Press, Chicago and London.

Repo, R. \& Winterhalter, B. (1968) Some observations on the weathering of limestone in glaciogenic material in the Lohja region, S. W. - Finland. Bull. Geol. Soc. Finland 40.

SAXÉN (SAKSELA), M. (1925) Om mangan-järnmalm fyndigheten i Vittinki. (Ref.: Das Eisen-Manganerzvorkommen von Vittinki). Fennia 45, 11.

Scheffer, F. \& Schachtschabel, P. (1966) Bodenkunde. Ferdinand Enke Verlag. Stuttgart.

Slavin, W. (1968) Atomic Absorption Spectroscopy. Interscience Publishers, New York.

StÅLfelt, M. G. (1965) Växtekologi. 2 uppl. Svenska Bokförlaget, Stockholm.

VILENSKII, D. G. (1957) Soil Science IPST, Jerusalem.

Winterhalter, B. (1966) Pohjanlahden ja Suomenlahden ranta-mangaanisaostumista. (Summary: Iron-manganese concretions from the Gulf of Bothnia and the Gulf of Finland). Geotekn. julk. No. 69.

Manuscript received, February 14, 1972. 